\title{
Noncoding RNA Expression Aberration Is Associated with Cancer Progression and Is a Potential Biomarker in Esophageal Squamous Cell Carcinoma
}

\author{
Hidetaka Sugihara ${ }^{1}$, Takatsugu Ishimoto ${ }^{1,2}$, Keisuke Miyake ${ }^{1}$, Daisuke Izumi ${ }^{1}$, \\ Yoshifumi Baba ${ }^{1}$, Naoya Yoshida ${ }^{1}$, Masayuki Watanabe ${ }^{3}$ and Hideo Baba ${ }^{1, *}$ \\ Received: 3 September 2015; Accepted: 16 November 2015; Published: 24 November 2015 \\ Academic Editor: Alan C. Leonard \\ 1 Department of Gastroenterological Surgery, Graduate School of Medical Science, Kumamoto University, \\ Kumamoto 860-8556, Japan; hidetaka1125@hotmail.com (H.S.); taka1516@kumamoto-u.ac.jp (T.I.); \\ technical.assistant.kugs01@gmail.com (K.M.); apple_morphine@yahoo.co.jp (D.I.); \\ baba@kumamoto-u.ac.jp (Y.B.); nyoshida@kumamoto-u.ac.jp (N.Y.) \\ 2 Cancer and Stem Cell Biology, Duke-National University of Singapore (NUS) \\ Graduate Medical School Singapore, Singapore 169857, Singapore \\ 3 Department of Gastroenterological Surgery, The Cancer Institute Hospital of Japanese Foundation For \\ Cancer Research (JFCR), Tokyo 135-8550, Japan; masayuki.watanabe@jfcr.or.jp \\ * Correspondence: hdobaba@kumamoto-u.ac.jp; Tel.: +81-96-373-5212; Fax: +81-96-371-4378
}

\begin{abstract}
Esophageal cancer is one of the most common cancers worldwide. Esophageal squamous cell carcinoma (ESCC) is the major histological type of esophageal cancer in Eastern Asian countries. Several types of noncoding RNAs (ncRNAs) function as key epigenetic regulators of gene expression and are implicated in various physiological processes. Unambiguous evidence indicates that dysregulation of ncRNAs is deeply implicated in carcinogenesis, cancer progression and metastases of various cancers, including ESCC. The current review summarizes recent findings on the ncRNA-mediated mechanisms underlying the characteristic behaviors of ESCC that will help support the development of biomarkers and the design of novel therapeutic strategies.
\end{abstract}

Keywords: esophageal squamous cell carcinoma; microRNA; long noncoding RNA; cancer initiation; cancer development; biomarker

\section{Introduction}

Esophageal cancer (EC) is known as one of the most aggressive cancers, as reflected by an overall survival rate of $10 \%-20 \%$. EC is the eighth most common cancer and the sixth most common cause of cancer death [1]. In EC cases diagnosed at an advanced stage, the overall five-year survival rate is $9 \%-40 \%$ [2]. EC is divided into two histological types, adenocarcinoma and squamous cell carcinoma. Although the incidence of esophageal adenocarcinoma is increasing, esophageal squamous cell carcinoma (ESCC) is more predominant in East Asia, including Japan. Despite improved development of multimodal techniques, such as surgery, chemotherapy and radiotherapy, the survival rate of ESCC patients remains poor because of a high incidence of local invasion and distant metastasis $[3,4]$. Therefore, identifying the mechanisms underlying these processes is critical for the development of biomarkers and therapeutic targets.

The human transcriptome contains numerous protein-coding messenger RNAs (mRNAs), as well as plenty of non-protein-coding transcripts. Among several kinds of noncoding RNAs (ncRNAs), long noncoding RNAs (lncRNAs) and microRNAs (miRNAs) have received attention in recent years. IncRNAs are a new class of ncRNAs that are longer than 200 nucleotides and regulate the expression levels of target genes in diverse biological processes, including chromatin 
modification, transcriptional and post-transcriptional levels [5-7]. Furthermore, recent studies have demonstrated that the expression of many lncRNAs is dysregulated, and they play critical roles in tumorigenesis and tumor progression in various types of cancer [8,9]. miRNAs are shorter noncoding RNAs (21-23 nucleotides) that bind to the $3^{\prime}$-untranslated region (UTR) of their target mRNAs to post-transcriptionally repress their translation. miRNAs have been involved in various pathological conditions, such as neurological diseases, cardiovascular disease, viral infection and cancer. A number of miRNAs target particular oncogenes or tumor suppressors and function in the pathogenesis of many cancers [10-12].

Accumulating evidence indicates that ncRNA dysregulation in ESCC plays an important role in regulating specific cellular processes, such as differentiation, proliferation, apoptosis and stress response. In addition, expression of these ncRNAs has the potential to serve as a useful biomarker for diagnosis and prognosis prediction in ESCC patients. In this review, we focus on the ncRNA-mediated mechanisms underlying tumor progression and the identification of diagnostic and prognostic prediction biomarkers in ESCC.

\section{Dysregulation of miRNAs Involved in ESCC Development}

Dysregulation of miRNAs has been shown to have an effect on tumor growth in ESCC (Figure 1). The development of ESCC is closely related to lifestyle habits, such as tobacco smoking and/or alcohol drinking, and chronic stimuli induce genetic and epigenetic alterations in normal esophageal mucosa. Several miRNAs have been reported to be implicated in lifestyle habit-related ESCC. Wang et al. showed that smoke exposure increased the risk for ESCC to induce single nucleotide polymorphisms in miR-423 [13]. Zinc deficiency (ZD) is also implicated in the development of ESCC [14]. A previous study showed that miR-31 and miR-21 overexpression caused by ZD was associated with inflammation and resulted in ESCC development in a rat model [15].

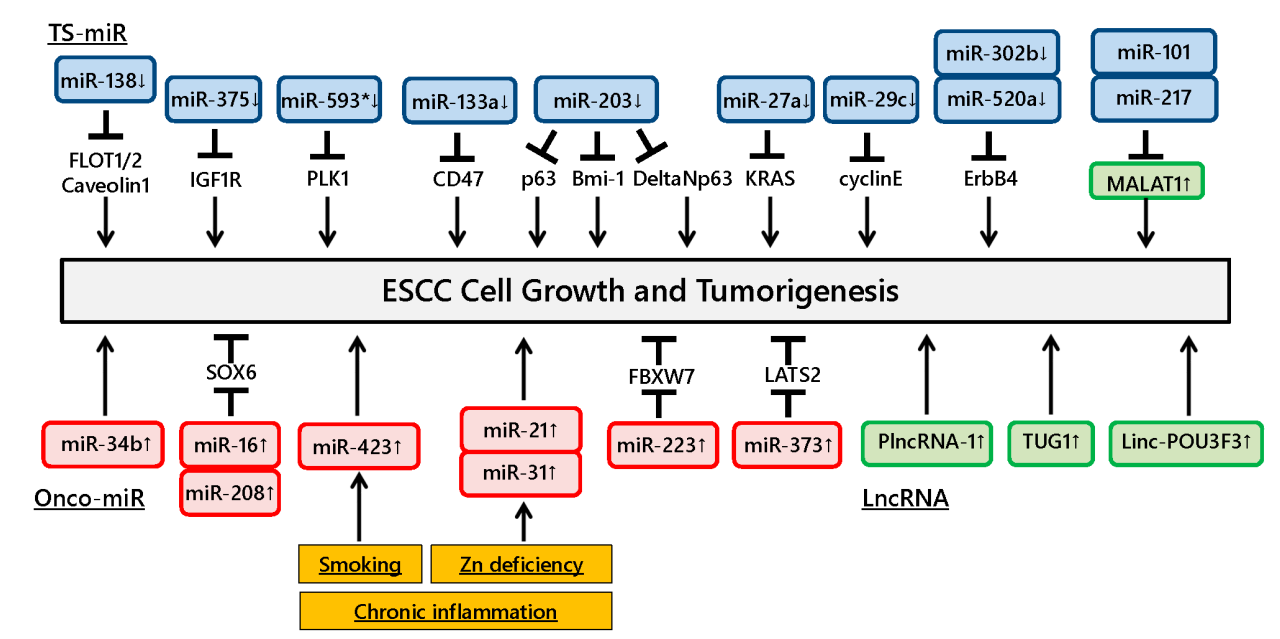

Figure 1. Dysregulation of ncRNAs involved in esophageal squamous cell carcinoma (ESCC) development. Dysregulation of various ncRNAs affects tumor growth in ESCC. Chronic inflammation induces ncRNA alterations in esophageal mucosa and affects downstream target gene regulation, thus contributing to ESCC development.

Ito et al. showed that miR-593* directly suppressed Polo-like kinase 1 expression and reduced ESCC growth [16]. Other studies demonstrated that miR-133a and miR-375 were downregulated in ESCC tissues and significantly inhibited tumorigenesis and growth through directly targeting CD47 and IGF1R, respectively $[17,18]$. Likewise, miR-29c was significantly downregulated in ESCC tissues and decreased tumor growth by causing cell cycle arrest mainly through suppressing cyclin E expression [19]. miR-302b and miR-520a were downregulated in ESCC and suppressed cell 
proliferation via binding the $3^{\prime}-\mathrm{UTR}$ of ErbB4 mRNA [20,21]. Furthermore, a recent study showed that miR-27a was downregulated and directly targeted the KRAS gene in ESCC cell lines and tissues, resulting in inhibited cell growth of ESCC [22]. Gong et al. found that downregulation of miR-138 induced lipid raft formation via upregulating multiple components of lipid rafts, including FLOT1, FLOT2 and caveolin-1, resulting in NF-KB activation and promotion of ESCC aggressiveness in vitro and in vivo [23].

Several studies have demonstrated the functional roles of miR-203 in ESCC progression. Yu et al. examined the expression of the stem renewal factor Bmi- 1 and miR-203 in ESCC side population (SP) and non-SP (NSP) cells and found that Bmi-1 was increased and miR-203 was decreased in SP cells compared to NSP cells. The authors also found that the SP cell fraction and colony formation were remarkably decreased in miR-203-overexpressing cells [24]. Yuan et al. reported that cell growth was inhibited in ESCC cells transfected with miR-203 mimic and $\triangle N$ p63 small interfering RNA, indicating that miR-203 could suppress cell proliferation in ESCC cells through the $\triangle \mathrm{Np} 63$-mediated signaling pathway [25]. Another study reported downregulated miR-203 expression in ESCC tissues and showed its involvement in ESCC cell growth in vitro and in vivo by regulating p63 expression [26].

In contrast, miR-34b and miR-373 were significantly overexpressed in ESCC tissues and promoted ESCC cell growth, and studies showed that miR-373 suppresses the expression of the large tumor suppressor, homolog $2[27,28]$. Likewise, other studies revealed that miR-16 and miR-208 were overexpressed in ESCC tissues and could promote cell proliferation by downregulating SOX6 [29,30]. Kurashige et al. demonstrated that miR-223 was upregulated in ESCC tissues and modulated the activity of F-box and WD repeat domain-containing 7, a cell cycle regulatory gene, leading to abnormal accumulation of c-Myc expression [31]. These findings suggest that the target gene regulation by various miRNAs is closely correlated with ESCC development and growth.

\section{3. miRNA Regulation of Resistance to Anticancer Drugs}

Understanding the mechanisms underlying drug resistance can lead to the development of novel therapeutic strategies in ESCC patients. Several miRNAs have been reported to regulate the resistance to anticancer drugs against ESCC. The expression levels of let-7b and let-7c were altered in cisplatin-resistant ESCC cells, and let-7c directly repressed the cisplatin-activated interleukin (IL)-6/STAT3 pro-survival pathway, leading to poor prognosis in ESCC patients [32]. Overexpression of miR-218 resulted in suppressed cell growth, colony formation, migration and invasion, caused cell apoptosis and arrested cell cycle in the G0/G1 phase. miR-218 mimics increased the sensitivity to the anti-tumor effect of cisplatin in ESCC cell lines through regulating the expression of phosphorylated PI3K, AKT and mTOR [33]. These results indicate that these miRNAs act as tumor-suppressive (TR) miRs related to the drug resistance of ESCC.

Conversely, previous studies have demonstrated the involvement of oncogenic miRNAs (onco-miRs) in the drug resistance of ESCC. One report showed that miR-141 induced resistance to cisplatin-induced apoptosis through targeting YAP1, and another study showed that miR-200c repressed PPP2R1B, a subunit of protein phosphatase 2A, and was also involved in drug resistance through the Akt pathway in ESCC cells [34,35]. Downregulation of miR-27a and miR-296 conferred sensitivity of both $P$-glycoprotein-related and $P$-glycoprotein-nonrelated drugs and promoted adriamycin-induced apoptosis by suppressing MDR1 expression [36,37]. These previous findings may show possible candidates for the development of individualized treatment against refractory ESCC.

\section{4. miRNAs Involved in ESCC Cell Migration and Invasion}

The motility of cancer cells is essential for invasion into blood vessels and spreading to the surrounding organs. One of the most common processes that induces the early steps of cancer metastasis is epithelial to mesenchymal transition (EMT). The expressions of miR-9, miR-25 and miR-92a, which regulate CDH1 expression, were shown to be upregulated in ESCC tissues and to 
promote cell migration and invasion [38-40]. In addition, Zhang et al. reported a positive association between miR-21 expression and cigarette smoking. Upregulation of miR-21 was also induced by nicotine in an ESCC cell line, promoting EMT via transforming growth factor- $\beta$ [41]. However, miR-205 and the miR-200 family suppressed tumor activities by EMT inhibition through targeting ZEB expression in ESCC cells [42,43].

Several studies have identified miRNAs that promote ESCC cell invasion. miR-21 and miR-183 promote ESCC cell growth and invasion through targeting PDCD4 [44,45]. Ohta et al. reported that the expression of miR-328, a candidate regulator of GNG7 mRNA, was inversely and significantly associated with GNG7 expression in 16 ESCC cell lines, suggesting that miR-328 could repress GNG7, leading to the invasiveness of ESCC cells and poor prognosis [46]. Li et al. showed that miR-21 was overexpressed in ESCC tissues and cell lines. Furthermore, knockdown of miR-21 significantly increased the expression of PTEN protein and consequently reduced cell proliferation, invasion and migration [47]. Tian et al. revealed that overexpression of miR-10b in ESCC cells increased cell motility and invasiveness induced by the suppression of endogenous KLF4 protein [48].

In contrast, other studies have identified miRNAs that suppress ESCC cell invasion. The expression of miR-100 was downregulated in ESCC tissues, and miR-100 modulated cell invasion through the repression of mTOR expression [49]. Overexpression of miR-625 inhibits cell proliferation and invasion through the repression of Sox2 [50]. miR-326 is involved in the regulation of VEGF-C-mediated cortactin expression and the subsequent invasion of ESCC cells [51]. Knockdown of FSCN1 or matrix metalloproteinase 14, one of the invadopodia-related proteins, and overexpression of miR-133a inhibited the growth and invasion of ESCC cells [52]. Ectopic expression of miR-195 induced G1 cell cycle arrest, leading to a significant decrease in cell growth, migration and invasion through the suppression of Cdc42 [53]. Zhang et al. showed that the overexpression of miR-200b or knockdown of Kindlin-2 in ESCC cells suppressed cell protrusion and focal adhesion (FA) formation and decreased cell spreading and invasiveness/migration. Furthermore, the authors demonstrated that Rho-family guanosine triphosphatases and FA kinase had an impact on the biological effects of the miR-200b-Kindlin-2 cascade [54].

Several studies have demonstrated important functions of miR-203. Takeshita et al. reported downregulation of miR-203 expression in ESCC tissues and showed that miR-203 played an important role in ESCC cell invasion by regulating LIM and SH3 protein 1 expression [55]. Another study revealed that overexpression of miR-203 in ESCC cells remarkably induced cell apoptosis and inhibited cell growth, migration and invasion via targeting small GTPase Ran [56]. The miRNAs involved in ESCC cell migration and invasion are summarized in Figure 2.

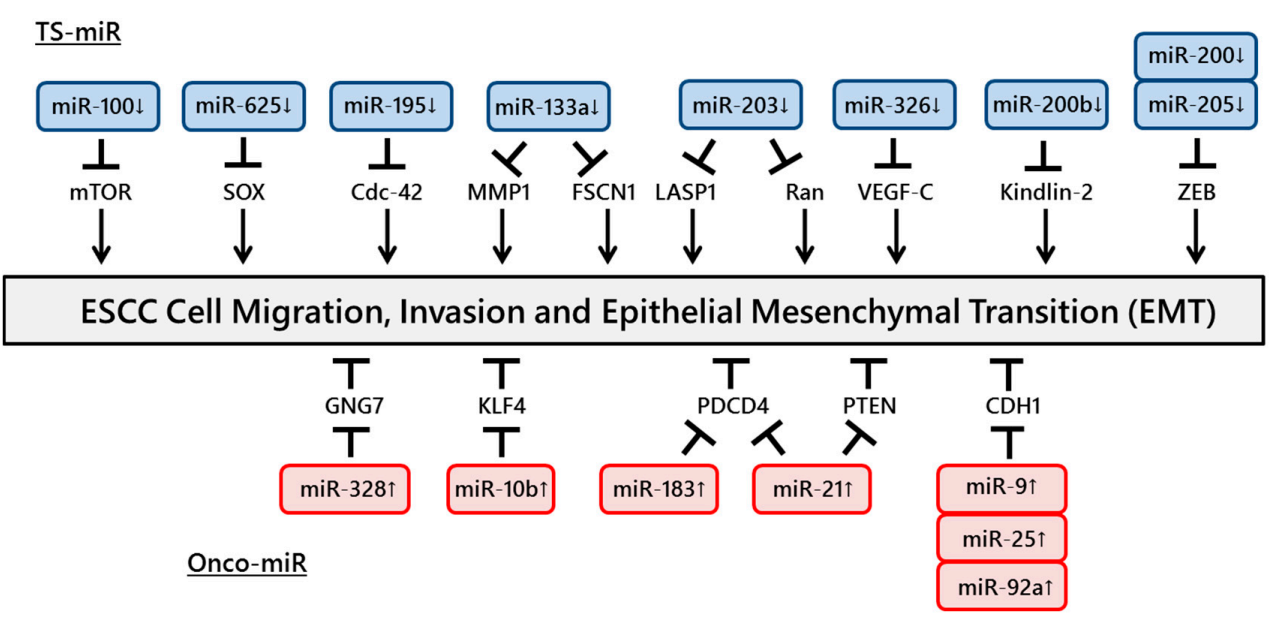

Figure 2. ncRNAs involved in ESCC cell migration and invasion. A number of ncRNAs regulate ESCC cell migration and invasion through targeting tumor suppressor genes or oncogenes. 


\section{5. miRNAs as Diagnostic and Prognostic Biomarkers in Primary ESCC Tissue}

The identification of effective diagnostic and prognostic prediction biomarkers is invaluable for the development of treatment strategies against ESCC (Table 1). Among the members of the miR-17-92 cluster, which have been reported to be highly expressed in several cancers, miR-17, miR-18a and miR-19a serve as potential unfavorable prognostic biomarkers and are associated with some clinicopathologic factors [57]. miRNA microarray analysis using 31 ESCC samples showed that high expressions of miR-103 and miR-107 were associated with poor prognosis in overall survival by multivariate analysis [58]. Fu et al. investigated 22 studies including a total of 1946 participants by searching PubMed, Embase and Web of Science to identify miRNAs that may function as prognostic biomarkers in ESCC. Among 33 prognostic miRNAs, miR-21 and miR-375 were selected, and further analysis revealed that upregulation of miR-21 and downregulation of miR-375 can predict unfavorable prognosis in ESCC [59].

\section{Plasma miRNAs as Noninvasive Biomarkers}

The identification of novel biomarkers in plasma/serum miRNA is required for early detection and prognostic prediction in ESCC (Table 1). A previous study showed that plasma concentrations of miR-19b and miR-25 were significantly higher in ESCC patients than in healthy volunteers, and plasma miR-25 levels were significantly downregulated in postoperative samples compared to preoperative samples and were significantly overexpressed in association with ESCC recurrence [60]. Another report showed that serum miR-1246 was markedly upregulated in ESCC patients and has the possibility of being a novel noninvasive biomarker for the early detection of ESCC [61]. Plasma concentrations of miR-18a, miR-21 and miR-375 were significantly higher in ESCC patients compared to healthy volunteers, and plasma levels of miR-18a were significantly lower in postoperative samples compared to preoperative samples [62,63]. Furthermore, the serum levels of miR-200c in ESCC patients were significantly higher than those in healthy volunteers, and high expression of miR-200c was significantly associated with poor response to chemotherapy [64].

In addition to plasma miRNAs, recent studies have focused on the detection of exosomal miRNAs. Tanaka et al. reported that the levels of miR-21 in exosomes were higher in patients with ESCC than those in the control group, and exosomal miR-21 expression was associated with advanced tumor stage, positive lymph node status and the presence of metastasis [65]. Taken together, this evidence shows that the search for definitive noninvasive biomarkers in plasma/serum is still in the preliminary stages, and further prospective studies are required in the future.

\section{Long Noncoding RNA Aberration in ESCC}

Several lncRNAs have been reported to function as potential oncogenes in ESCC (Figure 1). Metastasis associated with lung adenocarcinoma transcript 1 (MALAT1), a novel lncRNA, showed a significant impact on proliferation, invasion and metastasis of ESCC cells. Tumor-suppressive miRNAs (TS-miRs), miR-101 and miR-217, could suppress MALAT1 expression through posttranscriptional regulation [66]. The expression of PlncRNA-1 and taurine upregulated gene 1 (TUG1) were significantly upregulated in human ESCC compared to the adjacent normal tissues and induced ESCC cell proliferation $[67,68]$. Furthermore, long intergenic non-protein coding RNAs (lincRNAs) have been explored, and linc-POU3F3 was significantly upregulated in ESCC compared to corresponding normal tissues. RNA immunoprecipitation assays showed that linc-POU3F3 was associated with the enhancer of zeste homolog 2 (EZH2) mRNA. Overexpression of linc-POU3F3 in ESCC cell lines increased their proliferation, colony formation ability and tumorigenicity [69].

Several lncRNAs have the potential of being noninvasive biomarkers in plasma/serum for early detection and prognostic prediction of cancer (Table 1). Previous studies have shown that lncRNA HOX transcript antisense RNA (HOTAIR) was upregulated in ESCC tissues compared to the controls and correlated with the poor prognosis of ESCC patients. In addition, the functional investigation 
showed that HOTAIR contributed to the malignant behavior of ESCC cells, such as proliferation, anti-apoptosis, migration and invasion, through regulating diverse gene expression [70-73]. A recent study further identified a novel intronic HOTAIR enhancer and a functional ESCC susceptibility SNP rs920778 in Chinese populations [74]. Furthermore, several studies demonstrated that SPRY4-IT1, CCAT2 and prostate cancer-associated ncRNA transcript 1 (PCAT-1) were upregulated in ESCC tissues compared to the adjacent noncancerous tissues, and high expression of these lncRNAs was significantly associated with the clinical pathological stage and poor survival rate of ESCC [75-77]. On the other hand, LOC285194 expression was significantly downregulated in ESCC tissues and cell lines, and low expression of LOC285194 had a relationship with chemoradiotherapy resistance and unfavorable prognosis [78].

Plasma lncRNAs have also been explored, and the levels of POU3F3, HNF1A-AS1 and SPRY4-IT1 were significantly upregulated in plasma from ESCC patients. Among the three lncRNAs, POU3F3 showed the most reliable potential for detecting ESCC, suggesting that plasma POU3F3 could be a novel biomarker for the diagnosis of ESCC [79].

Table 1. Potential biomarkers in ESCC.

\begin{tabular}{|c|c|c|c|}
\hline Materials & Non-coding RNA Signature & Potential Value & Reference \\
\hline \multirow{8}{*}{ Primary tissues } & $\operatorname{miR}-17 \uparrow, \operatorname{miR}-18 \mathrm{a} \uparrow, \mathrm{miR}-19 \mathrm{a} \uparrow$ & Prognostic factor & [57] \\
\hline & $\operatorname{miR}-103 \uparrow, \operatorname{miR}-107 \uparrow$ & Prognostic factor & [58] \\
\hline & $\operatorname{miR}-21 \uparrow, \operatorname{miR}-375 \uparrow$ & Prognostic factor & [59] \\
\hline & HOTAIR $\uparrow$ & Prognostic factor & {$[70-74]$} \\
\hline & SPRY4-IT1 $\uparrow$ & Prognostic factor & [75] \\
\hline & CCAT $2 \uparrow$ & Prognostic factor & [76] \\
\hline & PCAT- $1 \uparrow$ & Prognostic factor & [77] \\
\hline & LOC285194 $\downarrow$ & $\begin{array}{l}\text { Prognostic factor; } \\
\text { responsiveness to chemoradiotherapy }\end{array}$ & [78] \\
\hline \multirow{6}{*}{ Plasma } & $\operatorname{miR}-19 \mathrm{~b} \uparrow, \mathrm{miR}-25 \uparrow$ & Screening marker & {$[60]$} \\
\hline & $\operatorname{miR}-1246 \uparrow$ & Screening marker & [61] \\
\hline & $\operatorname{miR}-18 \mathrm{a} \uparrow$ & Screening marker & {$[62]$} \\
\hline & $\operatorname{miR}-21 \uparrow, \operatorname{miR}-375 \uparrow$ & Screening marker & [63] \\
\hline & $\operatorname{miR}-200 \mathrm{c} \uparrow$ & $\begin{array}{l}\text { Screening marker; } \\
\text { responsiveness to chemoradiotherapy }\end{array}$ & {$[64]$} \\
\hline & POU3F3 $\uparrow$ & Screening marker & [79] \\
\hline Exosome & $\operatorname{miR}-21 \uparrow$ & Correlation with tumor progression & [65] \\
\hline
\end{tabular}

\section{Conclusions}

Accumulating evidence has suggested that ncRNAs play important roles in the initiation and development of ESCC. ESCC development is likely to be influenced by lifestyle factors, such as tobacco smoking and alcohol drinking, and these factors cause not only genomic alterations, but also dysregulation of various ncRNAs. Furthermore, the complex dysregulation of various ncRNAs is involved in the metastatic processes of ESCC cells. Previous studies for ncRNAs have reported a one-to-one relationship with a certain target gene, but actually, the ncRNA interacts with various genes. By establishing the model in vivo that genetically regulates the ncRNA expression, it will be possible to identify the most important ncRNA having an effect on ESCC development. This will lead to the design of novel strategies for ESCC treatment by targeting the ncRNA. To develop treatments that regulate distinct ncRNA-gene pathways, delivery systems for ncRNA modulators in ESCC tissue will be required before progressing to clinical application. Notably, several potential biomarkers related to ncRNAs in ESCC tissue or plasma have already been reported so far. However, clinical application of these candidates has not been accomplished at this time, because of the limit of sensitivity. Thus, further studies conducted in terms of ncRNAs are crucial to help further the development of useful biomarkers and successful therapeutic strategies against ESCC. 
Author Contributions: Hidetaka Sugihara and Takatsugu Ishimoto wrote the manuscript. Keisuke Miyake, Daisuke Izumi, Yoshifumi Baba, Naoya Yoshida and Masayuki Watanabe contributed to the manuscript conception and planning. Hideo Baba reviewed and proofread of the manuscript.

Conflicts of Interest: The authors declare no conflict of interest.

\section{References}

1. Jemal, A.; Bray, F.; Center, M.M.; Ferlay, J.; Ward, E.; Forman, D. Global cancer statistics. CA Cancer J. Clin. 2011, 61, 69-90. [CrossRef] [PubMed]

2. Jemal, A.; Siegel, R.; Xu, J.; Ward, E. Cancer statistics, 2010. CA Cancer J. Clin. 2010, 60, 277-300. [CrossRef] [PubMed]

3. Enzinger, P.C.; Mayer, R.J. Esophageal cancer. N. Engl. J. Med. 2003, 349, 2241-2252. [CrossRef] [PubMed]

4. Kimura, H.; Konishi, K.; Arakawa, H.; Oonishi, I.; Kaji, M.; Maeda, K.; Yabushita, K.; Tsuji, M.; Miwa, A. Number of lymph node metastases influences survival in patients with thoracic esophageal carcinoma: Therapeutic value of radiation treatment for recurrence. Dis. Esophagus 1999, 12, 205-208. [CrossRef] [PubMed]

5. Guttman, M.; Amit, I.; Garber, M.; French, C.; Lin, M.F.; Feldser, D.; Huarte, M.; Zuk, O.; Carey, B.W.; Cassady, J.P.; et al. Chromatin signature reveals over a thousand highly conserved large non-coding RNAs in mammals. Nature 2009, 458, 223-227. [CrossRef] [PubMed]

6. Gupta, R.A.; Shah, N.; Wang, K.C.; Kim, J.; Horlings, H.M.; Wong, D.J.; Tsai, M.C.; Hung, T.; Argani, P.; Rinn, J.L.; et al. Long non-coding RNA hotair reprograms chromatin state to promote cancer metastasis. Nature 2010, 464, 1071-1076. [CrossRef] [PubMed]

7. Tripathi, V.; Ellis, J.D.; Shen, Z.; Song, D.Y.; Pan, Q.; Watt, A.T.; Freier, S.M.; Bennett, C.F.; Sharma, A.; Bubulya, P.A.; et al. The nuclear-retained noncoding RNA MALAT1 regulates alternative splicing by modulating SR splicing factor phosphorylation. Mol. Cell 2010, 39, 925-938. [CrossRef] [PubMed]

8. Spizzo, R.; Almeida, M.I.; Colombatti, A.; Calin, G.A. Long non-coding RNAs and cancer: A new frontier of translational research? Oncogene 2012, 31, 4577-4587. [CrossRef] [PubMed]

9. Prensner, J.R.; Chinnaiyan, A.M. The emergence of lncRNAs in cancer biology. Cancer Discov. 2011, 1, 391-407. [CrossRef] [PubMed]

10. Kong, Y.W.; Ferland-McCollough, D.; Jackson, T.J.; Bushell, M. MicroRNAs in cancer management. Lancet Oncol. 2012, 13, e249-e258. [CrossRef]

11. Zhang, B.; Pan, X.; Cobb, G.P.; Anderson, T.A. MicroRNAs as oncogenes and tumor suppressors. Dev. Biol. 2007, 302, 1-12. [CrossRef] [PubMed]

12. Ishimoto, T.; Baba, H.; Izumi, D.; Sugihara, H.; Kurashige, J.; Iwatsuki, M.; Tan, P. Current perspectives towards the identification of key players in gastric cancer microRNA dysregulation. Int. J. Cancer 2015. [CrossRef] [PubMed]

13. Wang, Y.; Vogelsang, M.; Schafer, G.; Matejcic, M.; Parker, M.I. MicroRNA polymorphisms and environmental smoke exposure as risk factors for oesophageal squamous cell carcinoma. PLoS ONE 2013, 8, e78520. [CrossRef] [PubMed]

14. Abnet, C.C.; Lai, B.; Qiao, Y.L.; Vogt, S.; Luo, X.M.; Taylor, P.R.; Dong, Z.W.; Mark, S.D.; Dawsey, S.M. Zinc concentration in esophageal biopsy specimens measured by $\mathrm{X}$-ray fluorescence and esophageal cancer risk. J. Natl. Cancer Inst. 2005, 97, 301-306. [CrossRef] [PubMed]

15. Alder, H.; Taccioli, C.; Chen, H.; Jiang, Y.; Smalley, K.J.; Fadda, P.; Ozer, H.G.; Huebner, K.; Farber, J.L.; Croce, C.M.; et al. Dysregulation of miR-31 and miR-21 induced by zinc deficiency promotes esophageal cancer. Carcinogenesis 2012, 33, 1736-1744. [CrossRef] [PubMed]

16. Ito, T.; Sato, F.; Kan, T.; Cheng, Y.; David, S.; Agarwal, R.; Paun, B.C.; Jin, Z.; Olaru, A.V.; Hamilton, J.P.; et al. Polo-like kinase 1 regulates cell proliferation and is targeted by miR-593* in esophageal cancer. Int. J. Cancer 2011, 129, 2134-2146. [CrossRef] [PubMed]

17. Suzuki, S.; Yokobori, T.; Tanaka, N.; Sakai, M.; Sano, A.; Inose, T.; Sohda, M.; Nakajima, M.; Miyazaki, T.; Kato, H.; et al. CD47 expression regulated by the miR-133a tumor suppressor is a novel prognostic marker in esophageal squamous cell carcinoma. Oncol. Rep. 2012, 28, 465-472. [CrossRef] [PubMed] 
18. Kong, K.L.; Kwong, D.L.; Chan, T.H.; Law, S.Y.; Chen, L.; Li, Y.; Qin, Y.R.; Guan, X.Y. MicroRNA-375 inhibits tumour growth and metastasis in oesophageal squamous cell carcinoma through repressing insulin-like growth factor 1 receptor. Gut 2012, 61, 33-42. [CrossRef] [PubMed]

19. Ding, D.P.; Chen, Z.L.; Zhao, X.H.; Wang, J.W.; Sun, J.; Wang, Z.; Tan, F.W.; Tan, X.G.; Li, B.Z.; Zhou, F.; et al. miR-29c induces cell cycle arrest in esophageal squamous cell carcinoma by modulating cyclin $\mathrm{E}$ expression. Carcinogenesis 2011, 32, 1025-1032. [CrossRef] [PubMed]

20. Zhang, M.; Yang, Q.; Zhang, L.; Zhou, S.; Ye, W.; Yao, Q.; Li, Z.; Huang, C.; Wen, Q.; Wang, J. miR-302b is a potential molecular marker of esophageal squamous cell carcinoma and functions as a tumor suppressor by targeting ErbB4. J. Exp. Clin. Cancer Res. CR 2014, 33, 10. [CrossRef] [PubMed]

21. Ye, W.; Yao, Q.; Zhang, M.; Wen, Q.; Wang, J. miR-520a regulates ErbB4 expression and suppresses proliferation and invasion of esophageal squamous cell carcinoma. J. South. Med. Univ. 2014, 34, 164-168.

22. Jiang, Y.; Duan, Y.; Zhou, H. MicroRNA-27a directly targets to inhibit cell proliferation in esophageal squamous cell carcinoma. Oncol. Lett. 2015, 9, 471-477. [CrossRef] [PubMed]

23. Gong, H.; Song, L.; Lin, C.; Liu, A.; Lin, X.; Wu, J.; Li, M.; Li, J. Downregulation of miR-138 sustains NF-kB activation and promotes lipid raft formation in esophageal squamous cell carcinoma. Clin. Cancer Res. 2013, 19, 1083-1093. [CrossRef] [PubMed]

24. Yu, X.; Jiang, X.; Li, H.; Guo, L.; Jiang, W.; Lu, S.H. miR-203 inhibits the proliferation and self-renewal of esophageal cancer stem-like cells by suppressing stem renewal factor BMI-1. Stem Cells Dev. 2014, 23, 576-585. [CrossRef] [PubMed]

25. Yuan, Y.; Zeng, Z.Y.; Liu, X.H.; Gong, D.J.; Tao, J.; Cheng, H.Z.; Huang, S.D. MicroRNA-203 inhibits cell proliferation by repressing $\triangle \mathrm{Np} 63$ expression in human esophageal squamous cell carcinoma. BMC Cancer 2011, 11, 57. [CrossRef] [PubMed]

26. Okumura, T.; Shimada, Y.; Moriyama, M.; Takei, Y.; Omura, T.; Sekine, S.; Nagata, T.; Shimizu, K.; Tsukada, K. MicroRNA-203 inhibits the progression of esophageal squamous cell carcinoma with restored epithelial tissue architecture in vivo. Int. J. Oncol. 2014, 44, 1923-1932. [CrossRef] [PubMed]

27. Harata, K.; Ishiguro, H.; Kuwabara, Y.; Kimura, M.; Mitsui, A.; Ogawa, R.; Katada, T.; Tanaka, T.; Shiozaki, M.; Fujii, Y. MicroRNA-34b has an oncogenic role in esophageal squamous cell carcinoma. Oncol. Lett. 2010, 1, 685-689. [PubMed]

28. Lee, K.H.; Goan, Y.G.; Hsiao, M.; Lee, C.H.; Jian, S.H.; Lin, J.T.; Chen, Y.L.; Lu, P.J. MicroRNA-373 (miR-373) post-transcriptionally regulates large tumor suppressor, homolog 2 (lats2) and stimulates proliferation in human esophageal cancer. Exp. Cell Res. 2009, 315, 2529-2538. [CrossRef] [PubMed]

29. Zhu, Y.; Xia, Y.; Niu, H.; Chen, Y. miR-16 induced the suppression of cell apoptosis while promote proliferation in esophageal squamous cell carcinoma. Cell. Physiol. Biochem. 2014, 33, 1340-1348. [CrossRef] [PubMed]

30. Li, H.; Zheng, D.; Zhang, B.; Liu, L.; Ou, J.; Chen, W.; Xiong, S.; Gu, Y.; Yang, J. miR-208 promotes cell proliferation by repressing SOX6 expression in human esophageal squamous cell carcinoma. J. Transl. Med. 2014, 12, 196. [CrossRef] [PubMed]

31. Kurashige, J.; Watanabe, M.; Iwatsuki, M.; Kinoshita, K.; Saito, S.; Hiyoshi, Y.; Kamohara, H.; Baba, Y.; Mimori, K.; Baba, H. Overexpression of microRNA-223 regulates the ubiquitin ligase FBXW7 in oesophageal squamous cell carcinoma. Br. J. Cancer 2012, 106, 182-188. [CrossRef] [PubMed]

32. Sugimura, K.; Miyata, H.; Tanaka, K.; Hamano, R.; Takahashi, T.; Kurokawa, Y.; Yamasaki, M.; Nakajima, K.; Takiguchi, S.; Mori, M.; et al. Let-7 expression is a significant determinant of response to chemotherapy through the regulation of IL-6/STAT3 pathway in esophageal squamous cell carcinoma. Clin. Cancer Res. 2012, 18, 5144-5153. [CrossRef] [PubMed]

33. Tian, H.; Hou, L.; Xiong, Y.M.; Huang, J.X.; She, Y.J.; Bi, X.B.; Song, X.R. miR-218 suppresses tumor growth and enhances the chemosensitivity of esophageal squamous cell carcinoma to cisplatin. Oncol. Rep. 2015, 33, 981-989. [CrossRef] [PubMed]

34. Seki, N. A commentary on microRNA-141 confers resistance to cisplatin-induced apoptosis by targeting yap1 in human esophageal squamous cell carcinoma. J. Hum. Genet. 2011, 56, 339-340. [CrossRef] [PubMed] 
35. Hamano, R.; Miyata, H.; Yamasaki, M.; Kurokawa, Y.; Hara, J.; Moon, J.H.; Nakajima, K.; Takiguchi, S.; Fujiwara, Y.; Mori, M.; et al. Overexpression of miR-200c induces chemoresistance in esophageal cancers mediated through activation of the AKT signaling pathway. Clin. Cancer Res. 2011, 17, 3029-3038. [CrossRef] [PubMed]

36. Zhang, H.; Li, M.; Han, Y.; Hong, L.; Gong, T.; Sun, L.; Zheng, X. Down-regulation of miR-27a might reverse multidrug resistance of esophageal squamous cell carcinoma. Dig. Dis. Sci. 2010, 55, 2545-2551. [CrossRef] [PubMed]

37. Hong, L.; Han, Y.; Zhang, H.; Li, M.; Gong, T.; Sun, L.; Wu, K.; Zhao, Q.; Fan, D. The prognostic and chemotherapeutic value of miR-296 in esophageal squamous cell carcinoma. Ann. Surg. 2010, 251, 1056-1063. [CrossRef] [PubMed]

38. Song, Y.; Li, J.; Zhu, Y.; Dai, Y.; Zeng, T.; Liu, L.; Li, J.; Wang, H.; Qin, Y.; Zeng, M.; et al. MicroRNA-9 promotes tumor metastasis via repressing E-cadherin in esophageal squamous cell carcinoma. Oncotarget 2014, 5, 11669-11680. [CrossRef] [PubMed]

39. Xu, X.; Chen, Z.; Zhao, X.; Wang, J.; Ding, D.; Wang, Z.; Tan, F.; Tan, X.; Zhou, F.; Sun, J.; et al. MicroRNA-25 promotes cell migration and invasion in esophageal squamous cell carcinoma. Biochem. Biophys. Res. Commun. 2012, 421, 640-645. [CrossRef] [PubMed]

40. Chen, Z.L.; Zhao, X.H.; Wang, J.W.; Li, B.Z.; Wang, Z.; Sun, J.; Tan, F.W.; Ding, D.P.; Xu, X.H.; Zhou, F.; et al. MicroRNA-92a promotes lymph node metastasis of human esophageal squamous cell carcinoma via E-cadherin. J. Biol. Chem. 2011, 286, 10725-10734. [CrossRef] [PubMed]

41. Zhang, Y.; Pan, T.; Zhong, X.; Cheng, C. Nicotine upregulates microRNA-21 and promotes TGF- $\beta$-dependent epithelial-mesenchymal transition of esophageal cancer cells. Tumour Biol. 2014, 35, 7063-7072. [CrossRef] [PubMed]

42. Ohashi, S.; Natsuizaka, M.; Naganuma, S.; Kagawa, S.; Kimura, S.; Itoh, H.; Kalman, R.A.; Nakagawa, M.; Darling, D.S.; Basu, D.; et al. A notch3-mediated squamous cell differentiation program limits expansion of EMT-competent cells that express the zeb transcription factors. Cancer Res. 2011, 71, 6836-6847. [CrossRef] [PubMed]

43. Matsushima, K.; Isomoto, H.; Yamaguchi, N.; Inoue, N.; Machida, H.; Nakayama, T.; Hayashi, T.; Kunizaki, M.; Hidaka, S.; Nagayasu, T.; et al. miRNA-205 modulates cellular invasion and migration via regulating zinc finger E-box binding homeobox 2 expression in esophageal squamous cell carcinoma cells. J. Transl. Med. 2011, 9, 30. [CrossRef] [PubMed]

44. Hiyoshi, Y.; Kamohara, H.; Karashima, R.; Sato, N.; Imamura, Y.; Nagai, Y.; Yoshida, N.; Toyama, E.; Hayashi, N.; Watanabe, M.; et al. MicroRNA-21 regulates the proliferation and invasion in esophageal squamous cell carcinoma. Clin. Cancer Res. 2009, 15, 1915-1922. [CrossRef] [PubMed]

45. Ren, L.H.; Chen, W.X.; Li, S.; He, X.Y.; Zhang, Z.M.; Li, M.; Cao, R.S.; Hao, B.; Zhang, H.J.; Qiu, H.Q.; et al. MicroRNA-183 promotes proliferation and invasion in oesophageal squamous cell carcinoma by targeting programmed cell death 4. Br. J. Cancer 2014, 111, 2003-2013. [CrossRef] [PubMed]

46. Ohta, M.; Mimori, K.; Fukuyoshi, Y.; Kita, Y.; Motoyama, K.; Yamashita, K.; Ishii, H.; Inoue, H.; Mori, M. Clinical significance of the reduced expression of G protein gamma 7 (GNG7) in oesophageal cancer. Br. J. Cancer 2008, 98, 410-417. [CrossRef] [PubMed]

47. Li, P.; Mao, W.M.; Zheng, Z.G.; Dong, Z.M.; Ling, Z.Q. Down-regulation of PTEN expression modulated by dysregulated miR-21 contributes to the progression of esophageal cancer. Dig. Dis. Sci. 2013, 58, 3483-3493. [CrossRef] [PubMed]

48. Tian, Y.; Luo, A.; Cai, Y.; Su, Q.; Ding, F.; Chen, H.; Liu, Z. MicroRNA-10b promotes migration and invasion through KLF4 in human esophageal cancer cell lines. J. Biol. Chem. 2010, 285, 7986-7994. [CrossRef] [PubMed]

49. Zhang, N.; Fu, H.; Song, L.; Ding, Y.; Wang, X.; Zhao, C.; Zhao, Y.; Jiao, F.; Zhao, Y. MicroRNA-100 promotes migration and invasion through mammalian target of rapamycin in esophageal squamous cell carcinoma. Oncol. Rep. 2014, 32, 1409-1418. [CrossRef] [PubMed]

50. Wang, Z.; Qiao, Q.; Chen, M.; Li, X.; Wang, Z.; Liu, C.; Xie, Z. miR-625 down-regulation promotes proliferation and invasion in esophageal cancer by targeting SOX2. FEBS Lett. 2014, 588, 915-921. [CrossRef] [PubMed] 
51. Hong, C.C.; Chen, P.S.; Chiou, J.; Chiu, C.F.; Yang, C.Y.; Hsiao, M.; Chang, Y.W.; Yu, Y.H.; Hung, M.C.; Hsu, N.W.; et al. miR326 maturation is crucial for VEGF-C-driven cortactin expression and esophageal cancer progression. Cancer Res. 2014, 74, 6280-6290. [CrossRef] [PubMed]

52. Akanuma, N.; Hoshino, I.; Akutsu, Y.; Murakami, K.; Isozaki, Y.; Maruyama, T.; Yusup, G.; Qin, W.; Toyozumi, T.; Takahashi, M.; et al. MicroRNA-133a regulates the mRNAs of two invadopodia-related proteins, FSCN1 and MMP14, in esophageal cancer. Br. J. Cancer 2014, 110, 189-198. [CrossRef] [PubMed]

53. Fu, M.G.; Li, S.; Yu, T.T.; Qian, L.J.; Cao, R.S.; Zhu, H.; Xiao, B.; Jiao, C.H.; Tang, N.N.; Ma, J.J.; et al. Differential expression of miR-195 in esophageal squamous cell carcinoma and miR-195 expression inhibits tumor cell proliferation and invasion by targeting of CDC42. FEBS Lett. 2013, 587, 3471-3479. [CrossRef] [PubMed]

54. Zhang, H.F.; Zhang, K.; Liao, L.D.; Li, L.Y.; Du, Z.P.; Wu, B.L.; Wu, J.Y.; Xu, X.E.; Zeng, F.M.; Chen, B.; et al . miR-200b suppresses invasiveness and modulates the cytoskeletal and adhesive machinery in esophageal squamous cell carcinoma cells via targeting kindlin-2. Carcinogenesis 2014, 35, 292-301. [CrossRef] [PubMed]

55. Takeshita, N.; Mori, M.; Kano, M.; Hoshino, I.; Akutsu, Y.; Hanari, N.; Yoneyama, Y.; Ikeda, N.; Isozaki, Y.; Maruyama, T.; et al. miR-203 inhibits the migration and invasion of esophageal squamous cell carcinoma by regulating lasp1. Int. J. Oncol. 2012, 41, 1653-1661. [PubMed]

56. Zhang, F.; Yang, Z.; Cao, M.; Xu, Y.; Li, J.; Chen, X.; Gao, Z.; Xin, J.; Zhou, S.; Zhou, Z.; et al. miR-203 suppresses tumor growth and invasion and down-regulates miR-21 expression through repressing ran in esophageal cancer. Cancer Lett. 2014, 342, 121-129. [CrossRef] [PubMed]

57. Xu, X.L.; Jiang, Y.H.; Feng, J.G.; Su, D.; Chen, P.C.; Mao, W.M. MicroRNA-17, microRNA-18a, and microRNA-19a are prognostic indicators in esophageal squamous cell carcinoma. Ann. Thorac. Surg. 2014, 97, 1037-1045. [CrossRef] [PubMed]

58. Guo, Y.; Chen, Z.; Zhang, L.; Zhou, F.; Shi, S.; Feng, X.; Li, B.; Meng, X.; Ma, X.; Luo, M.; et al. Distinctive microRNA profiles relating to patient survival in esophageal squamous cell carcinoma. Cancer Res. 2008, 68, 26-33. [CrossRef] [PubMed]

59. Fu, C.; Dong, W.; Wang, Z.; Li, H.; Qin, Q.; Li, B. The expression of miR-21 and miR-375 predict prognosis of esophageal cancer. Biochem. Biophys. Res. Commun. 2014, 446, 1197-1203. [CrossRef] [PubMed]

60. Komatsu, S.; Ichikawa, D.; Hirajima, S.; Kawaguchi, T.; Miyamae, M.; Okajima, W.; Ohashi, T.; Arita, T.; Konishi, H.; Shiozaki, A.; et al. Plasma microRNA profiles: Identification of miR-25 as a novel diagnostic and monitoring biomarker in oesophageal squamous cell carcinoma. Br. J. Cancer 2014, 111, 1614-1624. [CrossRef] [PubMed]

61. Takeshita, N.; Hoshino, I.; Mori, M.; Akutsu, Y.; Hanari, N.; Yoneyama, Y.; Ikeda, N.; Isozaki, Y.; Maruyama, T.; Akanuma, N.; et al. Serum microRNA expression profile: miR-1246 as a novel diagnostic and prognostic biomarker for oesophageal squamous cell carcinoma. Br. J. Cancer 2013, 108, 644-652. [CrossRef] [PubMed]

62. Hirajima, S.; Komatsu, S.; Ichikawa, D.; Takeshita, H.; Konishi, H.; Shiozaki, A.; Morimura, R.; Tsujiura, M.; Nagata, H.; Kawaguchi, T.; et al. Clinical impact of circulating miR-18a in plasma of patients with oesophageal squamous cell carcinoma. Br. J. Cancer 2013, 108, 1822-1829. [CrossRef] [PubMed]

63. Komatsu, S.; Ichikawa, D.; Takeshita, H.; Tsujiura, M.; Morimura, R.; Nagata, H.; Kosuga, T.; Iitaka, D.; Konishi, H.; Shiozaki, A.; et al. Circulating microRNAs in plasma of patients with oesophageal squamous cell carcinoma. Br. J. Cancer 2011, 105, 104-111. [CrossRef] [PubMed]

64. Tanaka, K.; Miyata, H.; Yamasaki, M.; Sugimura, K.; Takahashi, T.; Kurokawa, Y.; Nakajima, K.; Takiguchi, S.; Mori, M.; Doki, Y. Circulating miR-200c levels significantly predict response to chemotherapy and prognosis of patients undergoing neoadjuvant chemotherapy for esophageal cancer. Ann. Surg. Oncol. 2013, 20 (Suppl. S3), S607-S615. [CrossRef] [PubMed]

65. Tanaka, Y.; Kamohara, H.; Kinoshita, K.; Kurashige, J.; Ishimoto, T.; Iwatsuki, M.; Watanabe, M.; Baba, H. Clinical impact of serum exosomal microRNA-21 as a clinical biomarker in human esophageal squamous cell carcinoma. Cancer 2013, 119, 1159-1167. [CrossRef] [PubMed]

66. Wang, X.; Li, M.; Wang, Z.; Han, S.; Tang, X.; Ge, Y.; Zhou, L.; Zhou, C.; Yuan, Q.; Yang, M. Silencing of long noncoding RNA MALAT1 by miR-101 and miR-217 inhibits proliferation, migration, and invasion of esophageal squamous cell carcinoma cells. J. Biol. Chem. 2015, 290, 3925-3935. [CrossRef] [PubMed] 
67. Wang, C.M.; Wu, Q.Q.; Li, S.Q.; Chen, F.J.; Tuo, L.; Xie, H.W.; Tong, Y.S.; Ji, L.; Zhou, G.Z.; Cao, G.; et al. Upregulation of the long non-coding RNA plncRNA-1 promotes esophageal squamous carcinoma cell proliferation and correlates with advanced clinical stage. Dig. Dis. Sci. 2014, 59, 591-597. [CrossRef] [PubMed]

68. Xu, Y.; Wang, J.; Qiu, M.; Xu, L.; Li, M.; Jiang, F.; Yin, R.; Xu, L. Upregulation of the long noncoding rna tug1 promotes proliferation and migration of esophageal squamous cell carcinoma. Tumour Biol. 2015, 36, 1643-1651. [CrossRef] [PubMed]

69. Li, W.; Zheng, J.; Deng, J.; You, Y.; Wu, H.; Li, N.; Lu, J.; Zhou, Y. Increased levels of the long intergenic non-protein coding RNA POU3F3 promote DNA methylation in esophageal squamous cell carcinoma cells. Gastroenterology 2014, 146, 1714-1726. [CrossRef] [PubMed]

70. Ge, X.S.; Ma, H.J.; Zheng, X.H.; Ruan, H.L.; Liao, X.Y.; Xue, W.Q.; Chen, Y.B.; Zhang, Y.; Jia, W.H. Hotair, a prognostic factor in esophageal squamous cell carcinoma, inhibits Wif-1 expression and activates Wnt pathway. Cancer Sci. 2013, 104, 1675-1682. [CrossRef] [PubMed]

71. Chen, F.J.; Sun, M.; Li, S.Q.; Wu, Q.Q.; Ji, L.; Liu, Z.L.; Zhou, G.Z.; Cao, G.; Jin, L.; Xie, H.W.; et al. Upregulation of the long non-coding RNA hotair promotes esophageal squamous cell carcinoma metastasis and poor prognosis. Mol. Carcinog. 2013, 52, 908-915. [CrossRef] [PubMed]

72. Li, X.; Wu, Z.; Mei, Q.; Li, X.; Guo, M.; Fu, X.; Han, W. Long non-coding RNA hotair, a driver of malignancy, predicts negative prognosis and exhibits oncogenic activity in oesophageal squamous cell carcinoma. Br. J. Cancer 2013, 109, 2266-2278. [CrossRef] [PubMed]

73. Lv, X.B.; Lian, G.Y.; Wang, H.R.; Song, E.; Yao, H.; Wang, M.H. Long noncoding RNA hotair is a prognostic marker for esophageal squamous cell carcinoma progression and survival. PLoS ONE 2013, 8, e63516. [CrossRef] [PubMed]

74. Zhang, X.; Zhou, L.; Fu, G.; Sun, F.; Shi, J.; Wei, J.; Lu, C.; Zhou, C.; Yuan, Q.; Yang, M. The identification of an ESCC susceptibility SNP RS920778 that regulates the expression of lncRNA hotair via a novel intronic enhancer. Carcinogenesis 2014, 35, 2062-2067. [CrossRef] [PubMed]

75. Xie, H.W.; Wu, Q.Q.; Zhu, B.; Chen, F.J.; Ji, L.; Li, S.Q.; Wang, C.M.; Tong, Y.S.; Tuo, L.; Wu, M.; et al. Long noncoding RNA SPRY4-IT1 is upregulated in esophageal squamous cell carcinoma and associated with poor prognosis. Tumour Biol. 2014, 35, 7743-7754. [CrossRef] [PubMed]

76. Zhang, X.; Xu, Y.; He, C.; Guo, X.; Zhang, J.; He, C.; Zhang, L.; Kong, M.; Chen, B.; Zhu, C. Elevated expression of CCAT2 is associated with poor prognosis in esophageal squamous cell carcinoma. J. Surg. Oncol. 2015, 111, 834-839. [CrossRef] [PubMed]

77. Shi, W.H.; Wu, Q.Q.; Li, S.Q.; Yang, T.X.; Liu, Z.H.; Tong, Y.S.; Tuo, L.; Wang, S.; Cao, X.F. Upregulation of the long noncoding RNA PCAT-1 correlates with advanced clinical stage and poor prognosis in esophageal squamous carcinoma. Tumour Biol. 2015, 36, 2501-2507. [CrossRef] [PubMed]

78. Tong, Y.S.; Zhou, X.L.; Wang, X.W.; Wu, Q.Q.; Yang, T.X.; Lv, J.; Yang, J.S.; Zhu, B.; Cao, X.F. Association of decreased expression of long non-coding RNA LOC285194 with chemoradiotherapy resistance and poor prognosis in esophageal squamous cell carcinoma. J. Transl. Med. 2014, 12, 233. [CrossRef] [PubMed]

79. Tong, Y.S.; Wang, X.W.; Zhou, X.L.; Liu, Z.H.; Yang, T.X.; Shi, W.H.; Xie, H.W.; Lv, J.; Wu, Q.Q.; Cao, X.F. Identification of the long non-coding RNA POU3F3 in plasma as a novel biomarker for diagnosis of esophageal squamous cell carcinoma. Mol. Cancer 2015, 14, 3. [CrossRef] [PubMed]

(C) 2015 by the authors; licensee MDPI, Basel, Switzerland. This article is an open access article distributed under the terms and conditions of the Creative Commons by Attribution (CC-BY) license (http:/ / creativecommons.org/licenses/by/4.0/). 